\title{
Perbedaan Kadar Glukosa Darah Antara Tikus Putih (Rattus Novergicus) yang Mendapat Asupan Susu Sapi dan Susu Kambing Segar
}

\author{
Hadi Oktafiano ${ }^{1}$, Husnil Kadri ${ }^{2}$, Dian Pertiwi ${ }^{3}$
}

\begin{abstract}
Abstrak
Susu adalah hasil ternak yang dikenal sebagai bahan makanan yang bernilai gizi tinggi. Sebagian masyarakat menganggap susu sapi segar dan susu kambing segar berpengaruh terhadap kadar glukosa darah. Tujuan penelitian ini adalah menentukan perbedaan glukosa darah tikus putih antara yang mendapat asupan susu sapi segar dan susu kambing segar. Jenis penelitian ini adalah eksperimental dengan rancangan pre and post test only group design. Sampel penelitian ini adalah 10 ekor tikus putih jantan (Rattus novergicus) yang dibagi menjadi 2 kelompok yaitu kelompok susu sapi segar dan susu kambing segar. Kedua kelompok diberikan diet susu dengan dosis setara 1 gelas susu (3,6 ml) selama 4 minggu (28 hari). Pengukuran kadar glukosa darah menggunakan blood glucose test meter. Hasil penelitian didapatkan rerata kadar glukosa kelompok susu sapi segar sebelum $(151,20 \pm 15,28 \mathrm{mg} / \mathrm{dl})$, setelah $(97,40 \pm 7.16 \mathrm{mg} / \mathrm{dl})$, sedangkan rerata kadar glukosa kelompok susu kambing segar sebelum $(133,80 \pm 5.80 \mathrm{mg} / \mathrm{dl})$, setelah $(97,80 \pm 7.88 \mathrm{mg} / \mathrm{dl})$. Uji statistik dengan $t$-test menyimpulkan terdapat perbedaan bermakna rerata kadar glukosa darah tikus putih sebelum dengan setelah mendapat asupan susu sapi segar dan susu kambing segar, tetapi tidak terdapat perbedaan bermakna rerata kadar glukosa darah tikus putih antara kelompok susu sapi segar dengan susu kambing segar setelah perlakuan.
\end{abstract}

Kata kunci: susu sapi segar, susu kambing segar, glukosa darah

\section{Abstract}

Milk is the result of cattle known as a food of high nutritional value. Some people think fresh cow's milk and fresh goat's milk effect on blood glucose levels. The objective of this study was to determine the differences in blood glucose levels of white rat (Rattus norvegicus) between that received fresh cow's milk and fresh goat's milk. This research was an experimental design with pre and posttest only group design. The sample was 10 male white rats (Rattus novergicus) divided into 2 groups:fresh cow's milk and goat's milk fresh. Both groups were given a diet of milk to equal 1 cup milk dose $(3.6 \mathrm{ml}$ ) for 4 weeks (28 days). Measurement of blood glucose levels using a blood glucose test meter. The results showed a mean glucose level before fresh cow's milk group $(151.20+15.28 \mathrm{mg} / \mathrm{dl})$, after $(97.40+7: 16 \mathrm{mg} / \mathrm{dl})$, whereas the mean glucose levels before the fresh goat milk group $(133.80+5.80 \mathrm{mg} / \mathrm{dl})$, after $(97.80+7.88 \mathrm{mg} / \mathrm{dl})$. The $t$-test results concluded that there is a significant difference in mean blood glucose levels before the white rat after receiving fresh cow's milk intake and fresh goat's milk, but there was no significant difference in mean blood glucose levels between groups of white rats fresh cow's milk with fresh goat's milk after treatment.

Keywords: fresh cow milk, fresh goat's milk, blood glucose

Affiliasi penulis: 1. Prodi Profesi Dokter FK UNAND (Faklutas Kedokteran Universitas Andalas Padang) 2. Bagian Biokimia FK UNAND, 3. Bagian Patologi Klinik FK UNAND

Korespondensi: Hadi Oktafiano, Email: hadioktafiano24@gmail.com Telp: 085263007399

\section{PENDAHULUAN}

Susu adalah hasil ternak yang dikenal sebagai bahan makanan yang bernilai gizi tinggi. Di dalam susu terdapat berbagai jenis zat gizi. Kandungan zat 
gizi susu dinilai lengkap dan dalam proporsi yang seimbang, sehingga susu bermanfaat menunjang pertumbuhan dan kesehatan tubuh, baik bagi anakanak, remaja, maupun dewasa. ${ }^{1}$

Susu yang banyak menyebar dan dikenal di pasaran adalah susu sapi. Sebenarnya susu kambing dan kerbau tidak kalah nilai gizinya dibandingkan dengan susu sapi. Hanya karena faktor kebiasaan dan ketersediaannya maka susu sapi lebih menonjol di pasaran. Beberapa daerah di Indonesia telah memanfaatkan susu kambing dan kerbau; Sumatera Utara, Sumatera Bara dan Sulawesi Selatan. ${ }^{2}$

Komposisi susu dapat sangat beragam tergantung pada beberapa faktor. Komposisi susu untuk susu sapi perah yang diambil rerata dari seluruh jenis sapi perah adalah lemak 3,9\%, protein 3,4\%, laktosa 4,8\%, abu 0,72\%, air $87,10 \%$. $^{3}$ Untuk komposisi susu kambing perah adalah lemak 4,9\%, protein $3,71 \%$, laktosa $4,20 \%$, abu $0,79 \%$, air $87,81 \%$.

Hasil survey di masyarakat didapatkan bahwa sebagian masyarakat mengatakan susu sapi atau susu kambing segar baik untuk menaikkan dan baik juga untuk menurunkan kadar glukosa darah dalam tubuh. Berdasarkan hal tersebut, perlu dilakukan penelitian karena belum ada pembuktian secara ilmiah tentang susu sapi atau susu kambing segar berpengaruh terhadap kadar glukosa darah dalam tubuh manusia.

\section{METODE}

Jenis penelitian ini adalah eksperimental dengan rancangan pre and post test only control group design dengan satu kelompok mendapat asupan susu sapi segar dan kelompok kedua mendapat asupan susu kambing segar.

Penelitian dan pengumpulan data dilakukan selama 6 bulan. Perlakuan pada tikus dilaksanakan dari Mei sampai Oktober 2014 di tempat pemeliharaan hewan di Andalas. Kriteria inklusi yaitu: tikus putih jantan (Rattus norvegicus), umur 2-3 bulan, dan berat badan 155 - 250 gram. Kriteria eksklusi yaitu: sampel dianggap drop out apabila selama penelitian, tikus putih jantan sakit dan mati.
Dalam penelitian ini digunakan lima ekor tikus untuk setiap kelompok. Teknik pemilihan sampel dalam penelitian ini dilakukan dengan cara random sampling.

Uji analisis dilakukan secara komputerisasi dengan uji $t$-test (sebaran data normal).

\section{Hasil}

Tabel 1. Nilai rerata kadar glukosa darah kelompok susu sapi segar

\begin{tabular}{lcc}
\hline \multicolumn{1}{c}{ Kelompok } & $\mathbf{n}$ & $\begin{array}{c}\text { Rerata } \mathbf{( m g / ~ d l )} \\
\mathbf{\pm S D}\end{array}$ \\
\hline Glukosa sebelum & 5 & $151.20 \pm 15.28$ \\
Glukosa setelah & 5 & $97.40 \pm 7.16$ \\
\hline
\end{tabular}

Pada Tabel 1 didapatkan nilai rerata kadar glukosa darah kelompok susu sapi segar sebelum dan setelah perlakuan.

Tabel 2. Perbedaan rerata kadar glukosa darah antara sebelum dan setelah pemberian susu sapi segar

\begin{tabular}{cccc}
\hline Kadar Glukosa & $\mathbf{n}$ & Rerata $(\mathbf{m g} / \mathbf{d l}) \pm$ SD & $\mathbf{p}$ \\
\hline sebelum - setelah & 5 & $53.80 \pm 22.37$ & 0.006 \\
& & & \\
\hline
\end{tabular}

Pada Tabel 2 didapatkan nilai rerata perbedaan kadar glukosa darah tikus putih kelompok susu sapi segar sebelum dengan setelah perlakuan bermakna secara statistik.

Tabel 3. Nilai rerata kadar glukosa darah kelompok susu kambing segar

\begin{tabular}{lll}
\hline Kelompok & $\mathbf{n}$ & Rerata $(\mathbf{m g} / \mathbf{d l}) \pm \mathbf{S D}$ \\
\hline Glukosa sebelum & 5 & $133.80 \pm 5.80$ \\
Glukosa setelah & 5 & $97.80 \pm 7.88$
\end{tabular}

Tabel 3 didapatkan nilai rerata kadar glukosa darah kelompok susu kambing segar sebelum dan setelah perlakuan. 
Tabel 4. Perbedaan rerata kadar glukosa darah antara sebelum dan setelah pemberian susu kambing segar

\begin{tabular}{cccc}
\hline Kadar Glukosa & $\mathbf{n}$ & Rerata $(\mathbf{m g} / \mathbf{d l}) \pm \mathbf{S D}$ & $\mathbf{p}$ \\
\hline Sebelum-sesudah & 5 & $36.00 \pm 3.16$ & 0.000
\end{tabular}

Pada Tabel 4 didapatkan perbedaan nilai rerata kadar glukosa darah tikus putih kelompok susu kambing segar sebelum dengan setelah perlakuan bermakna secara statistik.

Tabel 5. Perbedaan rerata kadar glukosa darah antara setelah pemberian susu sapi dan susu kambing segar

\begin{tabular}{llcc}
\hline \multicolumn{1}{c}{ Susu } & $\mathbf{n}$ & Rerata $(\mathbf{m g} / \mathbf{d l}) \pm$ SD & p \\
\hline Susu sapi & 5 & $97.40 \pm 7.12$ & \\
& & & \\
& & & \\
\hline $\begin{array}{l}\text { Susu } \\
\text { kambing }\end{array}$ & 5 & $97.80 \pm 7.88$ & \\
& & &
\end{tabular}

Pada Tabel 5 didapatkan nilai rerata perbedaan kadar glukosa darah tikus putih setelah perlakuan pada kelompok susu sapi segar dengan susu kambing segar tidak bermakna secara statistik.

\section{PEMBAHASAN}

\section{Pengaruh Pemberian Susu Sapi Segar Terhadap Kadar Glukosa}

Efek pemberian asupan susu sapi segar terhadap kadar glukosa darah tikus didapatkan rerata kadar glukosa sebelum perlakuan $151.20 \mathrm{mg} / \mathrm{dl}$ sedangkan setelah mendapat perlakuan $97.40 \mathrm{mg} / \mathrm{dl}$. Berdasarkan data tersebut, terjadi penurunan kadar glukosa darah tikus. Kadar glukosa darah tikus normal adalah 50-135 mg/dl. ${ }^{5}$ Pada uji statistik didapatkan perbedaan yang bermakna terhadap kadar glukosa darah sebelum dengan setelah mendapat asupan susu sapi segar dengan $(p<0.05)$. Hal ini menunjukkan bahwa efek pemberian susu sapi segar menurunkan kadar glukosa secara bermakna.

\section{Pengaruh Pemberian Susu Kambing Segar Terhadap Kadar Glukosa}

Efek pemberian asupan susu kambing segar terhadap kadar glukosa darah tikus didapatkan rerata kadar glukosa sebelum perlakuan $133.80 \mathrm{mg} / \mathrm{dl}$ sedangkan setelah mendapat perlakuan $97.80 \mathrm{mg} / \mathrm{dl}$.

Berdasarkan data tersebut, terjadi penurunan kadar glukosa darah tikus. Kadar glukosa darah tikus normal adalah 50-135 mg/dl. ${ }^{5}$ Pada uji statistik didapatkan perbedaan yang bermakna terhadap kadar glukosa darah sebelum dengan setelah mendapat asupan susu kambing segar $(p<0.05)$. Hal ini menunjukkan bahwa efek pemberian susu kambing segar menurunkan kadar glukosa secara bermakna.

\section{Perbedaan Rerata Kadar Glukosa Darah Antara Tikus Setelah Mendapat Asupan Susu Sapi Dan Susu Kambing Segar}

Perbedaan kadar glukosa darah antara tikus setelah mendapat asupan susu sapi dan susu kambing segar didapatkan rerata yaitu $97.40 \mathrm{mg} / \mathrm{dl}$ pada kelompok susu sapi segar dan $97.80 \mathrm{mg} / \mathrm{dl}$ pada kelompok susu kambing segar. Pada uji statistik tidak terdapat perbedaan bermakna terhadap kadar glukosa darah antara tikus setelah mendapat asupan susu sapi dan susu kambing segar ( $p>0.05)$. Hal ini menunjukkan bahwa perbedaan kadar glukosa darah antara kelompok susu sapi dan kelompok susu kambing segar tidak memiliki perbedaan yang bermakna.

Hal ini terjadi karena perbedaan komposisi susu sapi dengan susu kambing tidak jauh berbeda. Hasil penelitian ini menunjukkan bahwa terjadi penurunan kadar glukosa darah setelah mendapat asupan susu sapi dan susu kambing segar yang dibuktikan secara ilmiah.

\section{KESIMPULAN}

Terdapat perbedaan bermakna rerata kadar glukosa darah tikus putih sebelum dengan setelah mendapat asupan susu sapi segar.

Terdapat perbedaan bermakna rerata kadar glukosa darah tikus putih sebelum dengan setelah mendapat asupan susu kambing segar.

Tidak terdapat perbedaan bermakna rerata kadar glukosa darah antara tikus putih setelah asupan susu sapi segar dan susu kambing segar. 


\section{DAFTAR PUSTAKA}

1. Legowo AM. Sifat kimia, fisik dan mikrobiologi susu [serial online] 2002 (diunduh 2 Mei 2014). Tersedia dari: URL: HYPERLINK http://eprints.undip.ac.id/ 21247/1/1138-ki-fp-05.pdf

2. Saleh E. Dasar pengolahan susu dan hasil ikutan ternak [serial online] 2004 (diunduh 5 Mei 2014). Tersediadari: URL: HYPERLINK http://library.usu. ac.id/download/fp/ternak-eniza2.pdf
3. Dwidjoseputro D. Dasar - dasar mikrobiologi. Jakarta: Djambatan; 1994.

4. Sarwono B. Beternak kambing unggul. Jakarta: Penebar Swadaya; 2008.

5. Kusumawati D. Bersahabat dengan hewan coba. Jogjakarta: Gadjah Mada University Press; 2004. 